\title{
IMPLEMENTASI PROGRAM GERBANG SADU MANDARA DI DESA SANGSIT KECAMATAN SAWAN KABUPATEN BULELENG
}

\author{
PUTU AYU DESY RATNA DEWI, PUTU TRISNA EKA YANTI, LUH PUTRI \\ PERSIKA DEWI, KADEK AUS PUTRA SANJAYA, I PUTU UPADANA YUDI \\ MAHENDRA \\ Jurusan Akuntansi, Universitas Pendidikan Ganesha, Singaraja, Bali, Indonesia
}

\begin{abstract}
Abstrak
Penelitian ini bertujuan untuk mengetahui pengelolaan dana Gerbang Sadu Mandara di Desa Sangsit dan bagaimana implikasi dari peaksanaan program Gerbang Sadu Mandara teradap Masyaraat di Desa Sangsit. Metode dalam penelitian ini menggunakan metode kualitatif dengan sumber data primer dan sekunder. Dalam penelitian ini menggunakan teknik pengumpulan data dengan cara wawancara. Hasil dari penelitian ini yaitu program kemiskinan melalui Gerakan Pembangunan Desa Terpadu Mandara (Gerbang Sadu Mandara), dilaksanakan dengan sungguh-sungguh oleh pihakpihak yang terkait dalam program tersebut. Desa Sangsit sebagai salah satu desa penerima bantuan Gerbang Sadu Mandara, yang menerima bantuan pemerintah sebesar Rp.1.020.000.000,- untuk usaha/kegiatan ekonomi produktif masyarakat dan pembangunan infrastruktur. Program Gerbang Sadu Mandara yang dilaksanakan di Desa Sangsit pada tahun 2014, berdampak positif terhadap peningkatan kesejahteraan hidup masyarakat desa. Terjadi pengurangan jumlah pengangguran, meningkatnya pendapatan masyarakat miskin, merupakan dampak positif yang diakibatkan oleh adanya keberhasilan Program Gerakan Pembangunan Desa Terpadu Mandara (Gerbang Sadu Mandara) di Desa Sangsit.
\end{abstract}

Kata Kunci : Implementasi, Gerbang Sadu Mandara, Desa

\begin{abstract}
Sadu Mandara Gate in Sangsit Village and how to apply the Sadu Mandara Gate implementation program to the community in Sangsit Village. The method in this study uses qualitative methods with primary and secondary data sources. In this study using data collection techniques by interview. The result of this research is the poverty program through the Mandara Integrated Village Development Movement (Gerbang Sadu Mandara), carried out seriously by the parties involved in the program. Sangsit Village is one of the villages receiving the Gadu Sadu Mandara assistance, which receives government assistance in the amount of Rp.1,020,000,000, for community productive economic activities and infrastructure development. The Sadu Mandara Gate Program, which was implemented in Sangsit Village in 2014, had a positive impact on improving the welfare of village communities. The amount released, which was excluded from the poor population, was a positive result caused by the results of the Mandara Integrated Village Development Movement Program (Gerbang Sadu Mandara) in Sangsit Village.
\end{abstract}

Keywords: Implementation, Sadu Mandara Gate, Village

\section{Pendahuluan}

Dalam kamus ilmiah populer, kata "Miskin" mengandung arti tidak berharta (harta yang ada tidak mencukupi kebutuhan) atau bokek. Adapun kata "fakir" diartikan sebagai orang yang sangat miskin. Secara Etimologi makna yang terkandung yaitu bahwa kemiskinan sarat dengan masalah konsumsi. Hal ini bermula sejak masa neo-klasik di mana kemiskinan hanya dilihat dari interaksi negatif (ketidakseimbangan) antara pekerja dan upah yang diperoleh.

Kemiskinan juga dapat diartikan sebagai suatu keadaan dimana seseorang tersebut tidak dapat memenuhi kebutuhan hidup sehari-hari atau bisa dikatakan dengan suatu kondisi 
serba kekurangan dalam arti minimnya materi yang dimana mereka ini tidak dapat menikmati fasilitas pendidikan, pelayanan kesehatan, dan kemudahan-kemudahan lainnya yang tersedia pada jaman modern.

Seiring perkembangan ilmu pengetahuan dan teknologi, maka perkembangan arti definitif dari pada kemiskinan adalah sebuah keniscayaan. Berawal dari sekedar ketidakmampuan memenuhi kebutuhan konsumsi dasar dan memperbaiki keadaan hingga pengertian yang lebih luas yang memasukkan komponen-komponen sosial dan moral. Misal, pendapat yang diutarakan oleh Ali Khomsan bahwa kemiskinan timbul oleh karena minimnya penyediaan lapangan kerja di berbagai sektor, baik sektor industri maupun pembangunan. Senada dengan pendapat di atas adalah bahwasanya kemiskinan ditimbulkan oleh ketidakadilan faktor produksi, atau kemiskinan adalah ketidakberdayaan masyarakat terhadap sistem yang diterapkan oleh pemerintah sehingga mereka berada pada posisi yang sangat lemah dan tereksploitasi. Arti definitif ini lebih dikenal dengan kemiskinan struktural.

Kemiskinan dapat dibedakan menjadi tiga pengertian: kemiskinan absolut, kemiskinan relatif dan kemiskinan kultural. Seseorang termasuk golongan miskin absolut apabila hasil pendapatannya berada di bawah garis kemiskinan, tidak cukup untuk memenuhi kebutuhan hidup minimum: pangan, sandang, kesehatan, papan, pendidikan. Seseorang yang tergolong miskin relatif sebenarnya telah hidup di atas garis kemiskinan namun masih berada di bawah kemampuan masyarakat sekitarnya. Sedang miskin kultural berkaitan erat dengan sikap seseorang atau sekelompok masyarakat yang tidak mau berusaha memperbaiki tingkat kehidupannya sekalipun ada usaha dari pihak lain yang membantunya.

Kemiskinan adalah kondisi serba kekurangan dalam pemenuhan kebutuhan dasar manusia, yaitu kebutuhan-kebutuhan akan sandang pangan-papan, kebutuhan akan hidup yang sehat, dan kebutuhan akan pendidikan dasar bagi anak-anak. Penduduk miskin "tidak berdaya" dalam memenuhi kebutuhannnya, karena mereka tidak memiliki aset sebagai sumber pendapatan, dan struktur sosial-ekonomi, sosial budaya, dan sosial politik tidak membuka peluang orang miskin keluar dari lingkaran kemiskinan. Salah satu permasalahan yang dihadapi oleh pemerintah/negara indonesia adalah kemiskinan, dewasa ini pemerintah belum mampu menghadapi atau menyelesaikan permasalahan tersebut, padahal setiap mereka yang memimpin Negara Indonesia selalu membawa kemiskinan sebagai misi utama mereka disamping misi-misi yang lain. Remi dan Tjiptoherijanto (2002:1), mengatakan bahwa upaya menurunkan tingkat kemiskinan telah dimulai awal tahun 1970-an diantaranya melalui program Bimbingan Masyarakat (Bimas) dan Bantuan Desa (Bandes). Tetapi upaya tersebut mengalami tahapan jenuh pada pertengahan tahun 1980-an, yang juga berarti upaya penurunan kemiskinan di tahun 1970-an tidak maksimal, sehingga jumlah orang miskin pada awal 1990-an kembali naik. Disamping itu kecenderungan ketidakmerataan pendapatan melebar yang mencakup antar sektor, antar kelompok, dan ketidakmerataan antar wilayah.

Kondisi kemiskinan Indonesia semakin parah akibat krisis ekonomi pada tahun 1998. Namun ketika pertumbuhan ekonomi yang sempat menurun akibat krisis dapat teratasi dan dapat dipulihkan, kemiskinan tetap saja sulit untuk ditanggulangi. Pada tahun 1999, 27\% dari total penduduk Indonesia berada dalam kemiskinan. Sebanyak 33,9\% penduduk desa dan $16,4 \%$ penduduk kota adalah orang miskin. Krisnamurthi dalam Nyayu Neti Arianti, dkk, (2004:3).

Salah satu prasyarat keberhasilan pengentasan kemiskinan adalah dengan cara mengidentifikasi kelompok sasaran dan wilayah sasaran dengan tepat. Program pengentasan dan pemulihan nasib orang miskin tergantung dari langkah awal yaitu ketetapan mengidentifikasi siapa yang dikatakan miskin dan di mana dia berada. Aspek di mana "si miskin" dapat ditelusuri melalui si miskin itu sendiri serta melalui pendekatanpendekatan profil wilayah atau karakter geografis. Pada masa kepemimpinan SBY pemerintah indonesia juga meluncurkan program penanggulangan kemiskinan seperti BLT (Bantuan Langsung Tunai), KUR (Kredit Usaha Rakyat), pengembangan UMKM, PNPM Mandiri, dan masih banyak program-program lainnya, akan tetapi belum mampu mementaskan masyarakat indonesia dari jurang kemiskinan yang semakin hari semakin 
menyiksa dan menganiaya. Keadaan ini sudah seharusnya menjadi sebuah evaluasi diri bagi pemerintah untuk dapat terus merencanakan serta mengambil sebuah kebijakan yang dapat membawa indonesia keluar dari jurang kemiskinan. Tidak penulis pungkiri memang, bahwa usaha pemerintah dalam penanggulangan masalah kemiskinan sangatlah serius, bahkan merupakan salah satu program prioritas akan tetapi hasilnya belum cukup memuaskan.

Permasalahan kemiskinan merupakan permasalahan yang kompleks dan bersifat multidimensional, Oleh karena itu, upaya pengentasan kemiskinan harus dilakukan secara komprehensif, mencakup berbagai aspek kehidupan masyarakat, dan dilaksanakan secara terpadu (M. Nasir, dkk, dalam Adit Agus Prastyo, 2010:18). Dalam upaya penanggulangan kemiskinan ada dua strategi utama yang harus ditempuh oleh pemerintah. Pertama, melindungi keluarga dan kelompok masyarakat miskin melalui pemenuhan kebutuhan pokok mereka. Kedua, memberdayakan mereka agar mempunyai kemampuan untuk melakukan usaha dan mencegah terjadinya kemiskinan baru. Faktor mendasar yang menyebabkan kemiskinan diantaranya: SDM, SDA, Sistem, dan juga tidak terlepas dari sosok pemimpin, sehingga dimensi tersebut sangat berkaitan antara satu dengan yang lainnya. Kemiskinan terjadi karena kemampuan masyarakat pelaku ekonomi tidak sama, sehingga terdapat masyarakat yang tidak dapat ikut serta dalam proses pembangunan atau menikmati hasilhasil pembangunan. Soegijoko, (1997:137). Dengan kata lain yang kaya semakin kaya dan yang miskin semakin menderita.

Pemerintah beserta seluruh bangsa Indonesia telah berupaya semaksimal mungkin untuk segera bisa lepas dari krisis tersebut. Berbagai program telah dilaksanakan untuk menanggulangi kondisi tersebut, seperti melaksanakan program Jaring Pengaman Sosial (JPS), Inpres Desa Tertinggal (IDT), Pembangunan Prasarana Pendukung Desa Tertinggal (P3DT), Program Pengembangan Kecamatan (PPK), Program Nasional Pemberdayaan Masyarakat (PNPM) Mandiri. Juga telah pernah dilaksanakan program peningkatan kesejahteraan keluarga tertinggal melalui Program Keluarga Pra-Sejahtera (Pra-KS dan KS1) yang dimotori oleh BKKBN, serta program Bantuan Langsung Sementara Masyarakat (BLSM) yang merupakan pemberian dana secara tunai kepada Rumah Tangga Miskin (RTM) sebagai kompensasi kenaikan harga Bahan Bakar Minyak (BBM).

Provinsi Bali secara signifikan telah mencapai kemajuan terkait upaya pengurangan kemiskinan, yaitu dari 6,18\% pada tahun 2008 menurun menjadi 3,95 \% pada tahun 2013 . Namun dari banyak keberhasilan tersebut masih memerlukan penguatan lebih lanjut untuk mengupayakan penurunan jumlah angka penduduk dibawah garis kemiskinan. Pemerintah Provinsi Bali telah melakukan beberapa upaya melalui strategi dan kebijakan dalam peningkatan kesejahteraan dan pengurangan kemiskinan sebagaimana tertuang dalam visi Program Bali Mandara Jilid II yang dijabarkan lebih lanjut dalam Dokumen Strategi Penanggulangan Kemiskinan Daerah (SPKD). Sejalan dengan kebijakan di atas, sejak tahun 2012,Pemerintah Provinsi Bali mencanangkan program Gerakan Pembangunan Desa Terpadu Mandara(Gerbang Sadu Mandara), sebagai wadah bersama masyarakat perdesaan dalam membangun diri dan lingkungannya secara mandiri dan partisipatif, yang mencakup pembangunan infrastruktur pedesaan serta pengembangan usaha ekonimi produktif di perdesaan, menjadi salah satu program inti dalam percepatan penanggulangan kemiskinan di Provinsi Bali. Gerbang Sadu Mandara (GSM) merupakan program/kegiatan yang menempatkan upaya penanggulangan kemiskinan dan pengangguran serta pengurangan ketimpangan pembangunan antar wilayah ( Peraturan Gubernur Bali Nomor 52 Tahun 2013).

Prioritas utama kegiatan ini adalah meningkatkan kesejahteraan masyarakat miskin, dengan hasil yang ingin dicapai adalah : (1) menurunnya jumlah penduduk miskin dan terciptanya lapangan kerja yang mampu mengurangi tingkat pengangguran terbuka; (2) meningkatnya peran desa sebagai basis pertumbuhan ekonomi; (3) meningkatnya kualitas manusia secara menyeluruh tercermin dari membaiknya angka Indeks Pembangunan Manusia (IPM); (4) membaiknya mutu lingkungan hidup dan pengelolaan sumberdaya alam yang mengarah pada pembangunan berkelanjutan di seluruh sektor dan bidang pembangunan perdesaan; dan (6) membaiknya infrastruktur yang ditujukan oleh 
meningkatnya kuantitas dan kualitas berbagai sarana penunjang pembangunan. ( Peraturan Gubernur Bali Nomor 52 Tahun 2013).

Gerbang Sadu Mandara (GSM) berupaya mendorong pembangunan desa yang berbasis pada sosial ekonomi masyarakat. Lebih lanjut Gerbang Sadu Mandara diharapkan dapat mendorong kemandirian masyarakat dan desa dalam membangun diri dan lingkungannya secara mandiri melalui peningkatan pendapatan, sesuai dengan tujuan umumnya yaitu mempercepat pengentasan kemiskinan melalui pembangunan infrastruktur dan sosial ekonomi masyarakat di perdesaan dengan berbasis pada sumber daya local, mengangkat potensi desa, mengurangi kesenjangan antar wilayah dan untuk meningkatkan pendapatan masyarakat desa.

Sedangkan tujuan khusus dari program Gerbang Sadu Mandara adalah: (1) menumbuhkan kreativitas masyarakat dalam pemanfaatan potensi dan sumber daya alam yang ada secara optimal, lestari, dan berkelanjutan, serta meningkatkan pendapatan masyarakat desa agar secara bertahap mampu membangun diri dan lingkungannya secara mandiri; (2) menyediakan sarana dan prasarana dasar yang mendukung peningkatan usaha ekonomi dan pendapatan masyarakat perdesaan; (3) meningkatkan dan mengembangkan usaha ekonomi mokri sesuai dengan potensi dan sumberdaya local serta pengurangan pengangguran; dan (4) meningkatkan kapasitas dan partisipasi masyarakat dalam proses pembangunan infrastruktur dan sosial ekonomi secara partisipatif melalui rangkaian musyawarah pembangunan dari tingkat dusun hingga ke tingkat desa.

Selanjutnya sasaran dari program Gerbang Sadu Mandara ini adalah : (1)Terbangunnya infrastruktur dasar yang mendukung pengembangan sosial ekonomi masyarakat pedesaan dan kelurahan, meliputi pembangunan infrastruktur (prasarana) pada 6 (enam) kategori yaitu: (i) transportasi, (ii) produksi pertanian, (iii) pemasaran, (iv) air bersih dan sanitasi, (v) pendidikan, serta (vi) kesehatan; (2) Meningkatnya partisipasi seluruh masyarakat khususnya masyarakat miskin dan kelompok perempuan dalam pengembangan usaha ekonomi di perdesaan dan kelurahan; (3) Meningkatnya kemampuan Lembaga Kemasyarakatan Desa dan Kelurahan seperti Lembaga Pemberdayaan Masyarakat Desa dan kelurahan (LPMD/K)dan Pemberdayaan Kesejahteraan Keluarga (PKK) menjalankan fungsinya mengelola pembangunan partisipatif dalam pelaksanaan manajemen Gerbang Sadu Mandara; (4) Meningkatnya kapasitas Pemerintahan Desa dan Badan Permusyawaratan Desa (BPD) sebagai Pembina, pendamping, dan pengawas pengembangan sistem manajemen Gerbang Sadu Mandara; (5) Meningkatnya kapasitas Pemerintahan Kelurahan dan Lembaga Pemberdayaan Masyarakat (LPM) sebagai Pembina, pendamping, dan pengawas pengembangan sistem manajemen Gerbang Sadu Mandara; (6) Meningkatnya Kapasitas Kader Pemberdayaan Masyarakat (KPM) menjalankan perannya dalam menggerakkan partisipasi, swadaya dan gotong royong masyarakat dalam pembangunan desa dan kelurahan.

Gerbang Sadu Mandara mempunyai prinsip atau nilai-nilai dasar yang selalu menjadi landasan atau acuan dalam setiap pengambilan keputusan maupun tindakan yang akan diambil dalam pelaksanaan rangkaian kegiatan dan nilai-nilai tersebut diyakini mampu mendorong terwujudnya Bali Maju, Aman, Damai, dan Sejahtera (Mandara).

Prinsip-prinsip itu meliputi: 1) Bertumpu pada pembangunan manusia sesuai kearifan lokal. Pengertian pembangunan manusia berdasarkan kearifan lokal adalah masyarakat hendaknya memilih kegiatan yang berdampak langsung terhadap upaya pembangunan manusia daripada pembangunan fisik semata dan menjamin kegiatan yang akan dilaksanakan tidak bertentangan dengan kearifan lokal (adat dan sosial budaya) yang sudah ada di masyarakat. 2) Otonomi. Pengertian prinsip otonomi adalah masyarakat memiliki hak dan kewenangan mengatur diri secara mandiri dan bertanggung jawab, tanpa intervensi negative dari luar. 3) Desentralisasi. Pengertian prinsip desentralisasi adalah memberikan ruang yang lebih luas kepada masyarakat untuk mengelola kegiatan sektoral dan kewilayahan yang bersumber dari pemerintah dan pemerintah daerah sesuai dengan kapasitas masyarakat. 4) Berorientasi pada masyarakat miskin. Pengertian berorientasi pada masyarakat miskin adalah segala keputusan yang diambil berpihak kepada peningkatan kesejahteraan masyarakat khususnya masyarakat miskin. 5) Partisipasi. 
Pengertian prinsip partisipasi adalah masyarakat berperan secara aktif dalam proses atau alur tahapan program dan pengawasannya, mulai dari tahap sosialisasi, perencanaan, dan pelestarian kegiatan dengan memberikan sumbangan tenaga,pikiran, atau dalam bentuk materill. 6) Kesetaraan dan keadilan gender. Pengertian prinsip kesetaraan dan keadilan gender adalah masyarakat baik laki-laki dan perempuan mempunyai kesetaraan dalam perannya di setiap tahapan program dan dalam menikmati manfaat kegiatan pembangunan, kesetaraan juga dalam pengertian kesejajaran kedudukan pada saat situasi konflik. 7) Demokratis. Pengertian prinsip demokratis adalah masyarakat mengambil keputusan pembangunan secara musyawarah dan mufakat. 8) Transparansi dan Akuntabel. Pengertian transparansi dan Akuntabel adalah masyarakat memiliki akses terhadap segala informasi dan proses pengambilan keputusan sehingga pengelolaan kegiatan dapat dilaksanakan secara terbuka dan dapat dipertanggung jawabkan baik secara moral, teknis, legal, maupun administratif. 9) Prioritas. Pengertian prinsip prioritas adalah masyarakat memilih kegiatan yang diutamakan dengan mempertimbangkan kemendesakan dan kemanfaatan untuk pengentasan kemiskinan. 10) Keberlanjutan. Pengertian prinsip keberlanjutan adalah bahwa dalam setiap keputusan atau tindakan pembangunan, mulai dari tahap perencanaan, pelaksanaan, pengendalian dan pemeliharaan kegiatan harus telah mempertimbangkan system pelestariannya.

Desa Sangsit Kecamatan Sawan merupakan salah satu desa yang mendapat bantuan dana lewat Program Gerbang Sadu Mandara pada tahun 2013. Desa Sangsit meskipun letaknya tidak begitu jauh dengan kota Singaraja, tetapi jumlah Rumah Tangga Miskinnya (RTM) terbilang cukup besar yakni sekitar 13,1\% atau tepatnya 404 RTM dari 3079 Kepala Keluarga (KK) yang ada di Desa Sangsit. Dengan adanya bantuan dari Pemerintah Propinsi Bali melalui program Gerbang Sadu Mandara, diharapkan jumlah RTM tersebut bisa dikurangi.

Berdasarkan permasalahan diatas, rumusan masalah yang akan dirumuskan yaitu bagaimana pengelolaan dana Gerbang Sadu Mandara di Desa Sangsit dan bagaimana implikasi dari peaksanaan program Gerbang Sadu Mandara teradap Masyaraat di Desa Sangsit.

\section{Landasan Teori}

\section{Pergub Bali No 37 Tahun 2012 Tentang Gerbang Sadu Mandara}

Berikut alasan Pemerintah Provinsi Bali menetapkan Peraturan Gubernur Bali (Pergub Bali) No 37 Tahun 2012 tentang Petunjuk Teknis Bantuan Keuangan Kepada 77 Desa/Kelurahan melalui Program/ Kegiatan Gerakan Pembangunan Desa Terpadu Mandara (Gerbang Sadu Mandara) di Provinsi Bali diantaranya meliputi :

a) Bahwa dalam rangka optimalisasi penyelenggaraan pemerintahan, pelaksanaan pembangunan dan pembinaan kemasyarakatan desa/kelurahan di Provinsi Bali, perlu memberikan bantuan kepada pemerintah desa/kelurahan dari Anggaran Pendapatan dan Belanja Daerah Perubahan Provinsi Bali Tahun Anggaran 2012;

b) Bahwa agar pemberian bantuan kepada pemerintah desa/kelurahan di Provinsi Bali dapat berdayaguna dan berhasilguna, perlu dibuatkan Petunjuk Teknis Bantuan Keuangan Khusus Kepada 77 Desa/Kelurahan di Provinsi Bali Tahun 2012;

Maksud Penyusunan Petunjuk Teknis Bantuan Keuangan Khusus Kepada 77 Desa/Kelurahan Melalui Program/Kegiatan Gerakan Pembangunan Desa Terpadu Mandara (Gerbang Sadu Mandara) agar pembangunan sistem manajemen terpadu dapat mencapai tujuan dan sasaran yang telah ditetapkan secara efektif dan efisien khususnya dalam penanggulangan kemiskinan dan mengatasi kesenjangan antar wilayah perdesaan.

Tujuan Penetapan Petunjuk Teknis Bantuan Keuangan Khusus Kepada 77 Desa/Kelurahan Melalui Program/Kegiatan Gerakan Pembangunan Desa Terpadu Mandara (Gerbang Sadu Mandara) adalah:

a. Menumbuhkan kreativitas masyarakat dalam pemanfaatan potensi dan sumber daya alam yang ada secara optimal, lestari, dan berkelanjutan, serta meningkatkan pendapatan masyarakat dan desa/kelurahan agar secara bertahap mampu membangun diri dan lingkungannya secara mandiri; 
b. Menyediakan Prasarana dan Sarana dasar yang mendukung peningkatan usaha ekonomi dan pendapatan masyarakat perdesaaan/kelurahan;

c. Meningkatkan dan mengembangkan Usaha Ekonomi Mikro sesuai potensi dan sumberdaya lokal dan pengurangan pengangguran; dan

d. Meningkatkan kapasitas dan partisipasi masyarakat dalam proses pembangunan infrastruktur dan sosial ekonomi melalui rangkaian musyawarah pembangunan dari tingkat dusun/ lingkungan hingga ke tingkat desa/kelurahan.

Kegiatan Gerbang Sadu Mandara merupakan Program Pemerintah Provinsi, artinya program ini direncanakan, dilaksanakan dan didanai dari APBD Perubahan Provinsi Bali Tahun Anggaran 2012, melalui Bantuan Keuangan Khusus (BKK) GERBANG SADU MANDARA ke Desa/Kelurahan sebesar Rp. 1.020.000.000,- (satu milyar dua puluh juta rupiah) untuk masing-masing desa/kelurahan, akan menyasar sebanyak 77 desa/kelurahan. Dana GSM akan dikelola/dipergunakan untuk: membiayai Kegiatan Pembangunan Prasarana dan Sarana Dasar Perdesaan/Kelurahan maksimal sebanyak Rp. 200.000.000,$(20 \%)$ dan Pengembangan Usaha Perekonomian Masyarakat Perdesaan/Kelurahan khususnya penduduk miskin sebesar Rp. 800.000.000,- (80\%) dan sisanya dana Rp 20.000.000,- (dua puluh juta rupiah) untuk masing-masing desa/kelurahan dipergunakan antara lain untuk belanja honorarium pengelola kegiatan, belanja alat tulis kantor, biaya transportasi lokal, biaya konsumsi rapat-rapat, dan lain-lain dalam rangka pelaksanaan operasional GSM.

Sanksi adalah salah satu bentuk pemberlakuan kondisi dikarenakan adanya pelanggaran atas peraturan dan tata cara yang telah ditetapkan di dalam Gerbang Sadu Mandara. Sanksi bertujuan untuk menumbuhkan rasa tanggung jawab berbagai pihak terkait dalam pengelolaan kegiatan Gerbang Sadu Mandara.

Sanksi dapat berupa:

1) Sanksi masyarakat, yaitu sanksi yang ditetapkan melalui kesepakatan dalam musyawarah masyarakat. Semua kesepakatan sanksi dituangkan secara tertulis dan dicantumkan dalam Peraturan Desa/ Kelurahan tentang pelaksanaan Bantuan Keuangan Khusus Gerbang Sadu Mandara dan dalam berita acara pertemuan antara TPK dengan kelompok atau pribadi pengguna/pemanfaat kegiatan.

2) Sanksi hukum, yaitu sanksi yang diberikan sesuai dengan peraturan perundangan yang berlaku.

3) Sanksi program/kegiatan.

a. Kelompok masyarakat atau perseorangan pengguna/pemanfaat

Kelompok masyarakat atau perseorangan pengguna/pemanfaat tidak dapat mengelola Gerbang Sadu Mandara dengan baik, seperti menyalahi prinsipprinsip, menyalah gunakan dana dan penyimpangan prosedur, hasil kegiatan tidak terpelihara atau hasil kegiatan tidak dapat dimanfaatkan, maka bantuan diberhentikan untuk satu dusun/banjar dimana kelompok atau perseorangan berdomisili. Bantuan dapat diberikan kembali apabila segala prinsip-prinsip dan kerugian dikembalikan oleh kelompok masyarakat atau perseorangan pengguna/pemanfaat kegiatan Gerbang Sadu Mandara.

b. Sanksi kepada Tim Pelaksanan Kegiatan (TPK)

Apabila terdapat anggota TPK yang menyalah gunakan dana atau kewenangan dan atau penyimpangan prosedur, diberhentikan dari kepengurusan Gerbang Sadu Mandara dan wajib mengembalikan kerugian yang diakibatkan oleh tindakan yang bersangkutan atau TPK.

\section{Pergub Bali No 52 Tahun 2013 Tentang Gerbang Sadu Mandara}

Berikut alasan Pemerintah Provinsi Bali mengeluarkan atau menetapkan Peraturan Gubernur Bali (Pergub Bali) No 52 Tahun 2013 tentang Petunjuk Teknis Bantuan Keuangan kepada Desa melalui Program atau Kegiatan Gerakan Pembangunan Desa Terpadu Mandara (Gerbang Sadu Mandara) di Provinsi Bali adalah :

a) Bahwa dalam rangka optimalisasi penyelenggaraan pemerintahan pembangunan dan pembinaan kemasyarakatan di Desa di Provinsi Bali, perlu memberikan 
bantuan kepada Pemerintah Desa dari perubahan Anggaran Pendapatan dan Belanja Daerah Provinsi Bali Tahun Anggaran 2013.

b) Bahwa pemberian bantuan kepada Pemerintah Desa di Provinsi Bali dapat berdaya guna dan berhasilguna, maka perlu dibuatkan Petunjuk Teknis Bantuan Keuangan Khusus Kepada Desa di Provinsi Bali Tahun 2013.

\section{Metode Penelitian}

Dalam suatu penelitian, data merupakan faktor pendukung untuk mengkaji suatu permasalahan yang akan diteliti. Data - data yang akan digunakan dapat diperoleh dengan metode penelitian sebagai berikut:

\section{Jenis Penelitian}

Jenis penelitian yang digunakan dalam penelitian ini adalah penelitian kualitatif. Menurut Bungin (2012 : 32 ), penelitian kualitatif adalah penelitian yang menghasilkan data deskriptif mengenai kata-kata lisan maupun tertulis dan tingkah laku yang dpat diamati dari orang-orang yang diteliti. Sedangkan menurut Trianto (2009: 179) penelitian kualitatif adalah penelitian yang percaya bahwa kebenaran adalah dinamis dan dapat ditemukan hanya melalui penelaahan terhadap orang-orang melalui interaksinya dengan situasi sosial mereka. Pada penelitian kualitatif, penelitian dilakukan pada objek yang alamiah maksudnya, objek yang berkembang apa adanya, tidak dimanipulasi oleh peneliti dan kehadiran peneliti tidak begitu mempengaruhi dinamika pada objek tersebut.

Yang menjadi informan dalam penelitian ini terutama adalah Perbekel, tokoh masyarakat dan anggota masyarakat Desa Sangsit yang terlibat dalam program Gerbang Sadu Mandara. Informan tersebut ditunjuk secara purposive dengan mempertimbangkan pengetahuan mereka tentang masalah yang ditelaah.

Hal pertama yang dilakukan sebelum memulai seluruh tahapan penelitian kualitatif adalah menetapkan research question atau fokus penelitian ( Hendarso, 2007 : 170 ). Adapun yang menjadi fokus dalam penelitian ini adalah :

1. Pengelolaan dana Gerbang Sadu Mandara di Desa Sangsit.

2. Implikasi dari peaksanaan program Gerbang Sadu Mandara terhadap Masyarakat di Desa Sangsit.

Penelitian ini mengambil lokasi di Desa Sangsit Kecamatan Sawan Kabupaten Buleleng, dengan tujuan untuk mengetahui implementasi / pelaksanaan Program Gerbang Sadu Mandara yang merupakan program pemerintah Provinsi Bali dalam rangka penanggulangan kemiskinan. Selanjutnya pengumpulan data dengan mempergunakan teknik observasi, wawancara, dan pemanfaatan dokumen.

Analisis data dilakukan dengan menggunakan analisis kualitatif. Dalam hal ini analisis dilakukan sepanjang berlangsungnya penelitian dan dilakukan secara terus menerus (sirkuler) dari awal sampai akhir penelitian. Dalam melakukan kegiatan tersebut dilaksanakan berbagai tindakan, yakni tidak saja penggalian data yang intensif, tetapi disertai pula dengan kategorisasi data, penyusunan proposisi yang kesemuanya itu mendasarkan diri kepada perolehan data di lapangan.

Selain itu, kegiatan interpretasi data juga tidak akan diabaikan. Dengan mengacu kepada apa yang dikemukakan oleh Suparlan (2002 : 57) bahwa dalam interpretasi itu digunakan pendekatan interpretatif kualitatif, yakni penafsiran yang menggunakan pengetahuan, ide-ide, dan konsep-konsep yang ada pada masyarakat yang ditelaah.

\section{Sifat Penelitian}

Penelitian ini bersifat deskriptif karena ingin menggambarkan kenyataan yang terjadi di Desa Sangsit. Kenyataan tersebut mengenai bagaimana implementasi dari Program Pemerintah Provinsi Bali yaitu Gerbang Sadu Mandara di Desa Sangsit tersebut. Penelitian deskriptif bertujuan hipotesis boleh adamenggambarkan secara tepat sifat-sifat suatu individu, gejala, keadaan, atau kelompok tertentu, atau untuk menentukan ada tidaknya hubungan antara suatu gejala lain dalam suatu masyarakat. Dalam penelitian ini, teori-teori, ketentuan peraturan, norma-norma hokum danliteratur sudah mulai ada dan bahkan jumlahnya sudah cukup memadai sehingga dalam penelitian ini hipotesis boleh ada dan juga boleh tidak. 


\section{Lokasi Penelitian}

Lokasi penelitian yaitu di Kantor Desa milik Desa Sangsit Kecamatan Sawan Kabupaten Buleleng

\section{Data dan Sumber Data}

Data yang digunakan dalam penelitian ini bersumber dari 2 (dua) jenis data. Adapun 2 (dua) jenis data yang digunakan, yaitu:

a. Data primer

Data primer merupakan data yang diperoleh atau dikumpulkan oleh peneliti secara langsung dari sumber datanya. Penelitian ini bersumber dari penelitian yang langsung dilaksanakan di antor Desa Sangsit ecamatan Saan abuaten Bueeng. Data yang didapat secara langsung merupakan informasi yang diberikan oleh para informan, yaitu Kepala Desa.

b. Data sekunder

Data sekunder merupakan data yang diperoleh atau dikumpulkan peneliti dari berbagai sumber yang telah ada. Penelitian ini bersumber dari data - data yang sudah terdokumenkan dalam bentuk bahan - bahan hukum. Bahan hukum yang digunakan dalam penelitian ini, yaitu:

1. Bahan hukum primer

Bahan hukum primer bersumber dari peraturan perundang-undangan yang terkait dengan permasalahan yang dikaji. Peraturan perundang - undangan tersebut, antara lain:

a. Undang-undang Nomor 32 Tahun 2004 tentang Pemerintahan Daerah

b. Peraturan Presiden Nomor 54 Tahun 2010 tentang Pengadaan Barang/Jasa Pemerintah

c. Peraturan Pemerintah Nomor 72 Tahun 2005 tentang Desa;

d. Peraturan Pemerintah Nomor 73 tahun 2005 Tentang Kelurahan

e. Peraturan Menteri Dalam Negeri Nomor 13 Tahun 2006 tentang Pedoman Pengelolaan Keuangan Daerah, yang telah diubah dengan Peraturan Menteri Dalam Negeri Nomor 59 Tahun 2007 tentang Perubahan atas Peraturan Menteri Dalam Negeri Nomor 13 Tahun 2006 tentang Pedoman Pengelolaan Keuangan Daerah

f. Peraturan Pemerintah Nomor 8 Tahun 2008 tentang Tahapan, Tata Cara Penyusunan, Pengendalian dan Evaluasi Pelaksanaan Rencana Pembangunan Daerah

g. Peraturan Menteri Dalam Negeri Nomor 66 tahun 2007 Tentang Perencanaan Pembangunan Desa

h. Peraturan Menteri Dalam Negeri Nomor 67 tahun 2007 Tentang Pendataan Program Pembangunan Desa dan kelurahan

i. Peraturan Menteri Dalam Negeri Nomor 51 tahun 2007 Tentang Pembangunan Kawasan Perdesaan berbasis Masyarakat

j. Peraturan Menteri Dalam Negeri Nomor 5 tahun 2007 Tentang Pedoman Penataan Lembaga Kemasyarakatan

k. Perarturan Menteri Dalam Negeri Nomor 7 tahun 2007 Tentang Kader Pemberdayaan Masyarakat (KPM);

I. Perarturan Menteri Dalam Negeri No. 7 Tahun 2008 tentang pedoman tata cara pengawasan penyelenggaraan pemerintahan desa;

m. Instruksi Menteri Dalam Negeri Nomor 46 tahun 1994 Tentang Pemasyarakatan Pola Tata Desa;

n. Peraturan Daerah Provinsi Bali Nomor 12 Tahun 2009 tentang Pokok - pokok Pengelolaan Keuangan Daerah

o. Peraturan Daerah Nomor 6 Tahun 2010 tentang Anggaran Pendapatan dan Belanja Daerah (APBD) Provinsi Bali Tahun 2011.

2. Bahan hukum sekunder

Bahan hukum sekunder bersumber dari literatur-literatur, makalah-makalah, atau hasil penelitian yang berkaitan dengan permasalahan yang diteliti. 


\section{Teknik Pengumpulan Data}

Teknik pengumpulan data primer atau data lapangan dalam penelitian ini adalah menggunakan metode wawancara. Wawancara adalah teknik pengumpulan data yang dilakukan melalui tatap muka dan Tanya jawab langsung antara pengumpul data maupun peneliti terhadap narasumber atau sumber data.

Secara umum wawancara dapat dibagi kedalam 2 (dua) bagian yaitu standardized interview (wawancara berencana) dan unstandardized interview (wawancara tidak berencana). Model wawancara berencana biasanya daftar pertanyaan (kuisioner) telah disiapkan sebelumnya dan disusun secara sistematis. Kuisioner yang terstruktur dan sistematis ini kemudian oleh pewawancara ditanyakan kepada responden dengan cara membacakannya kepada responden untuk dijawa. Semua responden yang dipilih diajukan kuisioner yang sama, kata-kata yang sama dengan pola dan sistematika yang seraga pula. Sebaliknya, wawancara tidak berencana adalah wawancara yang sebelumnya tidakdibekali dengan persiapan penyusunan daftar pertanyaan dengan secara terpola dan sistematisyang mengharuskan dipatuhi oleh pewawancara. Dalam penelitian ini,dipergunakan teknik wawancara berencana, pertanyaan yang diajukan dalam wawancara kemudian dikembangkan lagi dengan cara memperdalam keterangan yang diberikan oleh informan. Hal ini dilakukan dengan tujuan untuk mendapatkan data yang lebih kompleks dan mendetail mengenai permasalahan yang akan diteliti. Adapun yang diwawancara dalam penelitian ini diantaranya adalah beberapa informan yaitu seperti Kepala Desa atau Perbekel Desa Sangsit, maupun pegawai-pegawainya. Untuk pengumpulan data sekunder digunakan teknik mencari dan mengumpulkan buku-buku literatur terkait dengan permasalahan yang dika jiserta membaca dan memahami dari literatur-lieratur tersebut.

\section{Teknik Pengolahan dan Analisis Data}

Dalam penelitian ini data dianalisis secara kualitatif atau juga sering dikenal dengan analisis deskriptif kualitatif. Analisis deskriptif kualitatif ini digunakan untuk menganalisis data yang diperoleh berdasarkan keseluruhan data yang terkumpul baik dari data primer maupun data sekunder, diklasifikasikan sesuai dengan permasalahan, kemudian dianalisis dengan teori dan konsep yang relevan, sehingga dapat menjawab permasalahan yang akan diteliti dan akhirnya data tersebut disajikan secara deskriptif kualitatif dan sistematis.

\section{Hasil dan Pembahasan}

\subsection{Pengelolaan Dana Gerbang Sadu Mandara di Desa Sangsit}

Pelaksanaan Gerbang Sadu Mandara diawali dengan adanya Kesepakatan Bersama Gubernur Bali dengan Bupati Buleleng, Tabanan, Badung, Gianyar, Bangli, Klungkung, dan Karangasem tentang Program/Kegiatan Gerakan Pembangunan Desa Terpadu Tahun 2013. Selanjutnya berdasarkan atas Peraturan Gubernur Bali Nomor : 52 Tahun 2013 tentang Petunjuk Teknis Bantuan Keuangan Khusus kepada Desa melalui Program/Kegiatan Gerakan Pembangunan Desa Terpadu Mandara ( Gerbang Sadu Mandara) di Provinsi Bali. Kemudian Badan Pemberdayaan Masyarakat dan Pemerintahan Desa (BPMPD) Provinsi Bali melakukan identifikasi dan verifikasi terhadap desa-desa sasaran yang akan memperoleh Bantuan Khusus Keuangan (BKK) melalui program Gerbang Sadu Mandara. Lokasi sasaran Gerbang Sadu Mandara melalui APBD Provinsi Bali difokuskan pada desa yang jumlah penduduk miskinnya didasarkan pada jumlah RTS dan jumlah KK (Kepala Keluarga) tebanyak pada desa-desa miskin dihitung secara absolut berdasarkan data PPLS 2011, yang terdapat di 6 (enam) kabupaten tersebut di atas.

Desa-desa yang telah ditetapkan sebagai lokasi sasaran Gerbang Sadu Mandara diwajibkan untuk membuat proposal tentang rencana pemanfaatan dana GSM yang didasarkan pada potensi desa, permasalahan yang ada di desa serta merumuskan perencanaan pembangunan bersama dengan lembaga-lembaga desa seperti Badan Permusyawaratan Desa (BPD), Lembaga Pemberdayaan Masyarakat (LPM), serta tokohtokoh masyarakat.

Desa Sangsit sebagai salah satu desa di Kabupaten Buleleng yang ditetapkan sebagai penerima Bantuan Khusus Keuangan (BKK) melalui program Gerbang Sadu Mandara lewat APBD Provinsi Bali tahun 2014 setelah proposalnya diterima oleh tim 
identifikasi dan verifikasi Provinsi Bali. Adapun jumlah bantuan yang diterima adalah sebesar Rp.1.020.000.000,- (satu milyar dua puluh juta ruliah).

Sebelum dana dari pemerintah Provinsi Bali sebesar Rp.1.020.000.000,- cair dan diterima oleh masyarakat, desa diwajibkan untuk mensosialisasikan kepada seluruh masyarakat terkait program Gerbang Sadu Mandara tersebut. Juga diwajibkan untuk membentuk Badan Usaha Milik Desa (BUMDes) yang ditetapkan melalui Peraturan Kepala Desa. BUMDes ini selanjutnya bertindak sebagai Tim pelaksana Kegiatan (TPK) Gerbang Sadu Mandara dalam bidang pengembangan usaha perekonomian masyarakat perdesaan.

Selanjutnya dana sebesar Rp.1.020.000.000,- dikelola oleh BUMDes "Sidi Amertha" dipergunakan untuk kegiatan seperti : usaha peternakan (sapi, babi, kambing, unggas), usaha industri kecil/rumah tangga, usaha simpan pinjam, pembangunan toko yadnya dan souvenir, serta pembangunan sarana air bersih.

Semua kegiatan yang dilaksanakan dalam program Gerbang Sadu Mandara di Desa Sangsit mendapatkan pemantauan, pengawasan dan evaluasi oleh pihak-pihak terkait. Tujuan dari kegiatan pengendalian (pemantauan, pengawasan, dan evaluasi) adalah untuk menjaga agar setiap proses Gerbang Sadu Mandara selalu sesuai dengan aturan, prinsip, dan kebijakan yang telah ditetapkan. Juga agar hasil-hasil dalam seluruh tahapan kegiatan diperoleh melalui proses dan mekanisme yang benar, serta sesuai dengan rencana yang telah ditentukan. Mengendalikan agar setiap pelaku Gerbang Sadu Mandara dapat menjalankan tugas dan tanggung jawabnya secara baik sesuai dengan fungsinya masingmasing.

Selanjutnya evaluasi dalam Gerbang Sadu Mandara dilakukan secara berkala terhadap seluruh kegiatan GSM di Desa Sangsit. Kegiatan evaluasi termasuk melakukan evaluasi perkembangan pengelolaan kegiatan, kualitas kegiatan, dan menilai hasil pelaksanaan usaha ekonomi masyarakat serta perkembangan BUMDes.

\subsection{Implikasi dari Pelaksanaan Program Gerbang Sadu Mandara Teradap Masyaraat di Desa Sangsit}

Dampak (impact) adalah akibat lebih jauh pada masyarakat sebagai konsekuensi adanya kebijakan yang diimplementasikan ( Subarsono, 2005 ). Sebagai salah satu kebijakan Pemerintah Provinsi Bali, dibawah kepemimpinan Gubernur Bali, I Made Mangku Pastika, Gerbang Sadu Mandara tentunya diharapkan memiliki dampak positif terhadap kehidupan masyarakat di perdesaan.

Program Gerbang Sadu Mandara di Desa Sangsit tahun 2014, bisa disebut berhasil. Hal ini bisa dilihat dari keberhasilan dari pelaksanaan kegiatan Gerbang Sadu Mandara yang diukur dengan beberapa indikator kinerja, yaitu : (1) Indikator Output, yakni tersalurkannya dana BKK sebesar Rp.1.020.000.000,- untuk Desa Sangsit sebagai pelaksana Gerbang Sadu Mandara; (2) Indikator Out come, tersedianya infrastruktur perdesaan dibangunnya kios-kios toko yadnya dan souvenir serta pemasangan pipa air bersih yang mengaliri 83 RTM di Banjar Sema dan Banjar Abasan ,dan terciptanya beberapa usaha ekonomi produktif perdesaan seperti usaha ternak dan unggas, keberadaan toko yadnya dan souvenir yang semakin berkembang; (3) Indikator Benefit, yakni menurunnya angka pengangguran dan tingkat kemiskinan serta meningkatnya lapangan pekerjaan di Desa Sangsit; dan (4) Indikator Impact (dampak) adalah meningkatnya pendapatan dan kesejahteraan masyarakat Desa Sangsit.

Menyadari akan pentingnya partisipasi masyarakat terhadap keberhasilan suatu kegiatan, maka masyarakat Desa Sangsit sangat antusias menyambut adanya bantuan dari pemerintah berupa program pengentasan kemiskinan lewat Bantuan Keuangan Khusus (BKK) melalui Gebang Sadu Mandara. Apalagi dana yang digelontorkan oleh Pemerintah Provinsi Bali untuk Desa Sangsit lumayan besar. Masyarakat Desa Sangsit berperan secara aktif dalam proses atau alur tahapan program dan pengawasannya, mulai dari tahap sosialisasi, perencanaan, dan pelestarian kegiatan dengan memberikan sumbangan tenaga, pikiran, atau dalam bentuk materil.

Partisipasi masyarakat dalam program Gerbang Sadu Mandara, lebih diprioritaskan pada keterlibatan secara aktif Rumah Tangga Miskin (RTM), sebagai kelompok sasaran 
(target group) dalam program pengentasan kemiskinan ini. Karena merekalah yang nantinya menjadi sasaran dari pendistribusian dana maupun pembangunan infrastruktur sebagai implementasi dari program GSM tersebut.

Partisipasi masyarakat tersebut sudah terlihat dari proses sosialisasi program GSM, perencanaan yang didalamnya melalui proses musyawarah penggalian gagasan berupa pertemuan kelompok-kelompok di dusun/banjar untuk menentukan gagasan-gagasan sesuai kebutuhan masyarakat terutama penduduk miskin/RTM. Dalam tahapan pelaksanaan kegiatan sampai pada pemantauan dan evaluasi juga melibatkan peran serta seluruh lapisan masyarakat.

\section{Simpulan}

Berdasarkan hasil penelitian, maka disimpulkan bahwa kemiskinan lewat Program Gerakan Pembangunan Desa Terpadu Mandara (Gerbang Sadu Mandara ), dilaksanakan dengan sungguh-sungguh oleh pihak-pihak yang terkait dalam program tersebut. Desa Sangsit sebagai salah satu desa penerima bantuan Gerbang Sadu Mandara, memanfaatkan dengan baik dana bantuan pemerintah sebesar Rp.1.020.000.000,- untuk usaha/kegiatan ekonomi produktif masyarakat dan pembangunan infrastruktur di desanya.

Keterlibatan secara aktif seluruh komponen masyarakat Desa Sangsit khususnya penduduk miskin/RTM dalam pelaksanaan program Gerbang Sadu Mandara menjadi kunci keberhasilan program tersebut. Masyarakat terlibat aktif pada semua alur tahapan program Gerbang Sadu Mandara, mulai dari sosialisasi, perencanaan, penggalian gagasan, pelaksanaan kegiatan, pengawasan, evaluasi sampai pada pelestarian kegiatan dalam hal ini memelihara usaha/kegiatan tersebut agar dapat bermanfaat bagi seluruh masyarakat.

Program Gerbang Sadu Mandara yang dilaksanakan di Desa Sangsit pada tahun 2014, berdampak positif terhadap peningkatan kesejahteraan hidup masyarakat desa. Terjadi pengurangan jumlah pengangguran, meningkatnya pendapatan masyarakat miskin, merupakan dampak positif yang diakibatkan oleh adanya keberhasilan Program Gerakan Pembangunan Desa Terpadu Mandara (Gerbang Sadu Mandara) di Desa Sangsit.

\section{Daftar Pustaka}

Abdul Wahab, Solichin, 2001, Analisis Kebijakan dari Formulasi ke Implementasi Kebijakan Negara,Jakarta : Bumi Aksara.

Bungin,Burhan, 2012,Analisis Data Penelitian Kualitatif : Pemahaman Filosofis ke Arah Penguasaan Model Aplikasi, Jakarta : Raja Grafindo Perkasa

Chaniago,Adrinof A., 2001, Gagalnya Pembangunan, Kajian Ekonomi Politik Terhadap Akar Krisis Indonesia, Jakarta : Pustaka LP3ES.

Gubernur Bali, 2013. Peraturan Gubernur Bali Nomor 52 Tahun 2013 tentang Petunjuk Teknis Bantuan Keuangan Khusus Kepada Desa Melalui Program/Kegiatan Gerakan Pembangunan Desa terpadu Mandara (Gerbang Sadu Mandara) di Provinsi Bali.

Hendarso,Emy Susanti, 2007. Metode penelitian Sosial,Berbagai Alternatif Pendekatan dalam Bagong Suyanto dan Sutinah (ed), Penelitian Kualitatif : Sebuah Pengantar, Jakarta : Kencana Prenada Media Group.

Islamy, Irfan, 2001, Prinsip-Prinsip Perumusan Kebijaksanaan Negara, Jakarta : Bumi Aksara.

Moleong, Lexy J., 2000,Metodologi Penelitian Kualitatif, Bandung : Remaja Karya.

Muhadjir,Noeng, 2007. Metodelogi Keilmuan (Paradigma Kualitatif, Kuantitatif dan Mixed), Yogyakarta : Rake Sarasin.

Soesastro, Hadi dkk, 2005. Pemikiran dan Permasalahan Ekonomi Di Indonesia dalam Setengah Abad Terakhir. Kanisius, Yogyakarta

Soetrisno,Loekman, 1995, Menuju Masyarakat Partisipatif, Yogyakarta: Kanisus.

Subarsono,AG.,2011,Analisis Kebijakan Publik-Konsep,Teori dan Aplikasi, Yogyakarta : Pustaka Pelajar.

Suprapta,I Nyoman, 2004, Persoalan Dasar dalam Proses Pembangunan dan Faktor-Faktor yang Mempengaruhi (Kajian Teori Ekonomi Pembangunan) dalam Widyatech Jurnal 
Sains dan Teknologi Vol.4 No.1 Agustus 2004, Singaraja : P3M Universitas Panji Sakti.

Tianto, 2009, Pengantar Penelitian Pendidikan bagi Pengembangan Profesi Pendidik dan Tenaga Kependidikan, Jakarta : Kencana

Winarno,Budi, 2010, Kebijakan Publik-Teori dan Proses, Yogyakarta : Media Presindo. 